\title{
DeVelopMent of A Potential BeAver HABITAT MODEL FOR THE SNAKE RIVER BASIN in Grand TETON NATIONAL PARK, WYOMING
}

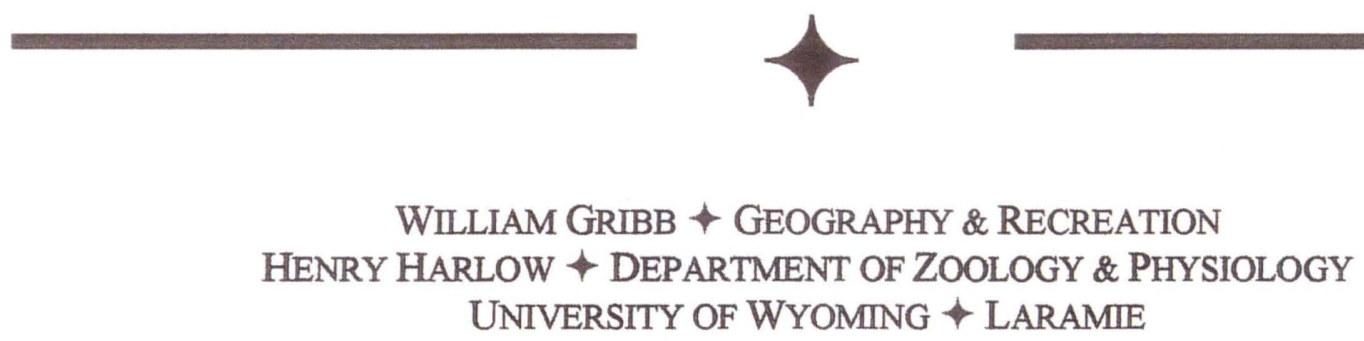

\section{$+\quad$ JUSTIFICATION AND SCOPE}

Our National Parks house some of North America's most undisturbed habitat and offer a benchmark for comparing ecosystem dynamics with areas more influenced by human related perturbations. Dam construction has altered water flow patterns on many of our country's rivers resulting in species composition changes of aquatic plants, invertebrates and fish. Semi-aquatic mammals such as otters and beaver are also profoundly influenced by the irregular seasonal flow patterns resulting from reservoir release schedules. For example, Jackson Lake dam was constructed in 1910 resulting in the impoundment of an additional 625,000 cubic feet of water. Since its construction and the establishment of Grand Teton National Park (GTNP), this water has been released during mid- to late summer months causing unpredictable fluctuations of river levels after the normal spring run off. This unpredictability is illustrated by the trend in water flow on the Snake River at Moran for the period 1904-2000 (Figure 1).

A species that has received little attention in terms of population numbers and resistance to abnormal water fluctuations resulting from Jackson Dam is the beaver (Castor canadensis). In GTNP, only the work of Collins (1976) has provided any significant knowledge of the distribution and habitat of the beaver in the Park. In fact, the beaver has been generally overlooked in the Greater Yellowstone Area with only a few studies conducted in Yellowstone
(Warren, 1926; Jonas, 1955; Consolo-Murphy and Hanson, 1993).

Figure 1. Yearly Stream Flows, Moran, May, $1904-2000$

छ

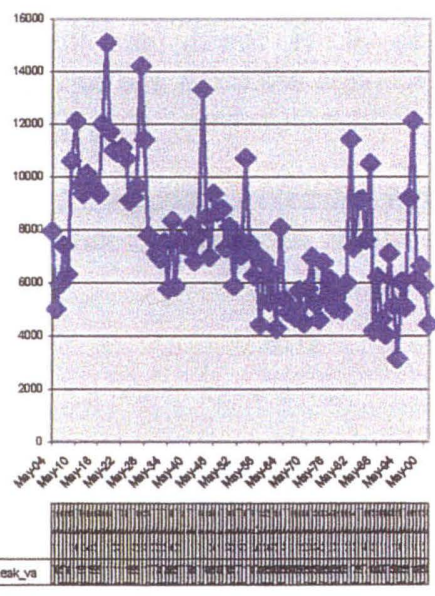




\section{$\downarrow \quad$ SIGNIFICANCE}

In 1976, Collins identified 51 active bank dens and lodges along the Snake River from Jackson Lake Dam to Moose. He also found an additional 47 abandoned dens and lodges. The surveys in Yellowstone National Park by Consolo-Murphy and Hanson (1993) and Consolo-Murphy and Tatum (1995) found roughly the same percentage of active (56\%) and non-active (44\%) dens and lodges out of 127 dens and lodges observed. Unfortunately, it is not known if the Collins and Murphy studies used the same definitions for active and non-active sites. But, the Collins study provides a baseline upon which to compare present and future studies on the amount of beaver activity along the Snake River, its immediate tributaries and its back-channels. In an elementary calculation of 51 bank dens and lodges along the 35.4 $\mathrm{km}$ channel from Jackson Lake Dam to Moose, the spatial distribution of dens/lodges from the Collins study was approximately 1.4 dens/lodges per $\mathrm{km}$. In a six year study of Manitoba beavers, Wheatley (1994) found that their average summer range was approximately 10.34 ha. Assuming these beaver would not forage more than $200 \mathrm{~m}$ from water, this would space colonies approximately $1 \mathrm{~km}$ apart. Breck, Wilson and Anderson (2001), however, found that the density of beaver colonies along the Yampa and Green Rivers were .35 colonies $/ \mathrm{km}$ and .55 colonies $/ \mathrm{km}$ respectively, less than one-half of Collins' findings.

One factor that may influence the distribution of beavers along the Snake River is pattern of the river's flow regime. The release of water from Jackson Lake is irregular during a year and over consecutive years. Figure 1. illustrates this point quite distinctly. The low periods are typically in the winter months increasing to the peak flows in midsummer, atypical of the natural peak spring runoff sequences pre-Jackson Lake Dam. The managed flows, however, also produced a flow almost twice the May average flow (7615 cfs) in 1997, with a peak of over 12,100 csf (Figure 2.). Several authors have recognized the impacts of the changes in flood regimes to plant and animal distribution and abundance (Lytle, 2002; Kingsford, 2000; Nilsson and Dynesius, 1994; and Nilsson, et al., 1991). According to Breck, Wilson and Andersen (2001) little is known about the impacts of flow regulation on beaver populations. In fact, there are differing opinions as to whether or not the population increases or decreases with stable flows. They do state that beaver density is a function of the availability of forage, thus if flood regimes improve riparian vegetation (Hughes and Cass, 1997) then there should be an increase in beavers. However, if stable flow decreases riparian vegetation regeneration and diversity the opposite should occur. Beavers are very selective in their forage (Long, 2000) preferring willow, aspen, poplar and cottonwood. The beaver is a vegetarian and will consume not just its preferred tree species but also water plants and grasses. Further, they eat all aspects of the tree or plant, including the outer bark, leaves, buds, seeds, flowers and specifically the cambium. Breck, Wilson and Andersen (2001) concluded in their study of responses to flow regulation, that beaver habitat conditions were better on the regulated Green River because of the increased availability of willows and experienced a decrease in predation because the willows were an island-oriented species.

Figure 2. Average Monthly Snake River Flow, Moran, 1903-2000

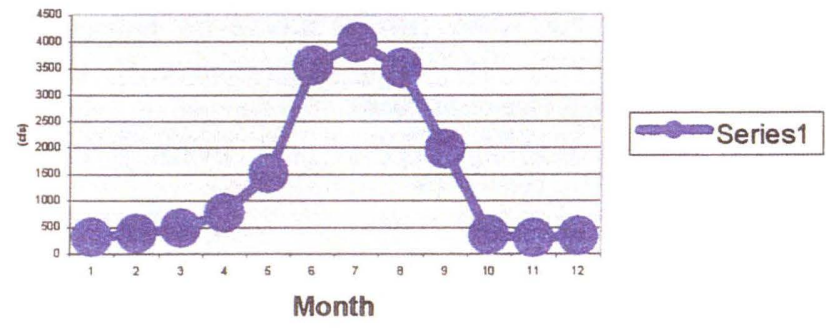

Allen (1983) constructed a beaver habitat suitability index model so that it would be possible to predict potential locations of beavers in a riverine landscape and to assist in beaver reintroduction programs. Incorporating GIS and remote sensing technologies, Johnston and Naiman (1990) somewhat successfully attempted to identify those habitats and examine the role of the beaver in an overall ecosystem. It is well documented that beaver have a dramatic impact on vegetation communities (Snodgrass, 1997), aquatic vertebrate as well as invertebrate populations (Collen and Gibson, 2000; Olson and Hubert, 1994), and hydro-geomorphic processes (Meentemeyer and Butler, 1998; Gurnell, 1998). But, the dynamics of this influence is limited by lack of knowledge of the beaver population. A comparison of changes over the past 25 years, since the work of Collins (1976), will offer insight into the population distribution.

\section{$\downarrow \quad$ PROJECT OBJECTIVES}

A complete baseline survey of beaver distribution and habitats on the Snake River above and below the Jackson Lake Dam was conducted. 
However, because of logistical constraints, this initial project was limited to the Snake River from Flagg Ranch to its delta into Jackson Lake and from the Jackson Lake dam along the main course of the Snake River to Moose, a total of $48 \mathrm{~km}$. It did not include the tributaries to the Snake River or the multitude of back channels on the Snake River. This project has the following objectives:

1.) obtain current remote sensed images, mainly aerial photography, of potential beaver habitats and identify distinguishable evidence of beaver activity.

2.) establish a field observation and measurement strategy for determining beaver activity and locations

3.) utilizing GPS and GIS technologies, map the location of beaver activities as well as habitat characteristics.

4.) test the Allen beaver habitat suitability index model to the observed beaver habitat.

5.) evaluate the Allen habitat model for beavers by adjusting the model's parameters to Grand Teton National Park.

6.) identify modifying factors that would influence beaver distribution and habitat.

7.) compare these data to that of Collins (1976).

8.) use these data as a foundation upon which a more comprehensive study can be conducted to establish a baseline survey of beaver distribution and numbers for GTNP.

\section{\ METHODOLOGY}

Four different research techniques were employed in this project: aerial photo interpretation; field data collection; GIS analysis; and statistical modeling techniques. Aerial photography was flown on June 27, 2002, with an average scale of 1:1,600. The imagery was collected for the entire length of the study area, Flagg Ranch to Moose. The imagery was obtained to assist in locating potential and active beaver areas. Aerial photography interpretation works best if using the normal interpretive factors or an identification key. From this photography, 16 potential and active areas were identified and assisted in locating sites.

Field inspection of identified potential and active beaver areas was conducted during June and August, 2002, totaling three weeks. Researchers reconnoitered the $48 \mathrm{~km}$ along the Snake River from Flagg Ranch to its delta into Jackson Lake and from Jackson Lake dam to Moose. The field inspection was a combination of river bank walking and rafting/canoeing the main channel of the Snake River. Each lodge and bank den identified was located using GPS technology. If the den was active, based on construction activity and observable markings of beaver presence, a more detailed inspection and data collection transpired. A vegetation cover inventory was taken at each active lodge/den site. This inventory consisted of collecting the vegetation information in six grid cells $(30 \mathrm{~m} \times 30 \mathrm{~m})$ systematically positioned with respect to the den or lodge. The cells were centered $60 \mathrm{~m}$ upstream from the den, at the den, and $60 \mathrm{~m}$ downstream from the den. A parallel set of three cells were positioned the same distances up- and down stream from the den but, $60 \mathrm{~m}$ interior to the bank. All of the information was spatially-referenced so that it could be employed in the GIS.

The different environmental factors used to develop the Allen (1983) beaver habitat model were collected so that they could be employed in a GIS for analysis. To populate the different model factors, the field data along with digital environmental data were acquired from available sources (NPS, 2002; WGISC, 2002) or captured from mapped and remote sensed images. Finally, computer modeling and statistical testing is the last of the techniques employed to complete the research objectives. The model would produce a probability matrix of beaver location based on the modified-HSI factors. The model could then be tested against the found locations.

\section{$\downarrow \quad$ ANALYSIS \\ The Allen habitat suitability index (HSI) (1982) identifies fifteen different parameters for hydrology and vegetation depending on the cover type (riverine, wetlands, or lacustrine). The cover type for this research was identified as riverine and wetlands. The hydrology parameters for these two cover types are: average annual water fluctuations and percent stream gradient. Though not requiring all of the different vegetation parameters, the parameters for riverine and wetlands areas are: percent tree canopy closure; percent trees in 2.5 to $15.2 \mathrm{~cm}$ dbh size class; percent shrub crown closure; average height of shrub canopy; and species composition of woody vegetation.}

The two hydrologic parameters in the HSI are average annual water fluctuations and percent stream gradient. Hydrologic differences occur both between years and within a year. As mentioned previously, Figure 1. illustrates the differences between years for the Moran gaging station (located $1 \mathrm{~km}$ downstream 
from the Jackson Lake dam), with an average May flow of $7615 \mathrm{cfs}$ that fluctuates by an average of 2275 cfs per year. In extreme cases the flow increased by $5510 \mathrm{cfs}$ in one year (1943-1944) and decreased by $6340 \mathrm{cfs}$ between 1986 and 1987 . The impacts on the stream channel and floodplain are not just the differences in flow, but the percent change in flow from one year to another. In 1993 to 1994 the flow increased almost $93 \%$, though the initial flow was below average $(3120 \mathrm{cfs})$. In 1986 the flow had decreased by slightly over $60 \%$ but in this year the initial flow was above average $(10,500 \mathrm{cfs})$ and came back to less than average. Figure 2 demonstrates the monthly variations in stream flow, peaking generally in June or July. The stream flows, however, vary significantly between the three gaging stations along the Snake River-Flagg Ranch (upstream from Jackson Lake), Moran, and Moose (located $35 \mathrm{~km}$ downstream from Jackson Lake Dam) (Figure 3.).

Figure 3. Snake River Profile, Flagg Ranch to Moose,

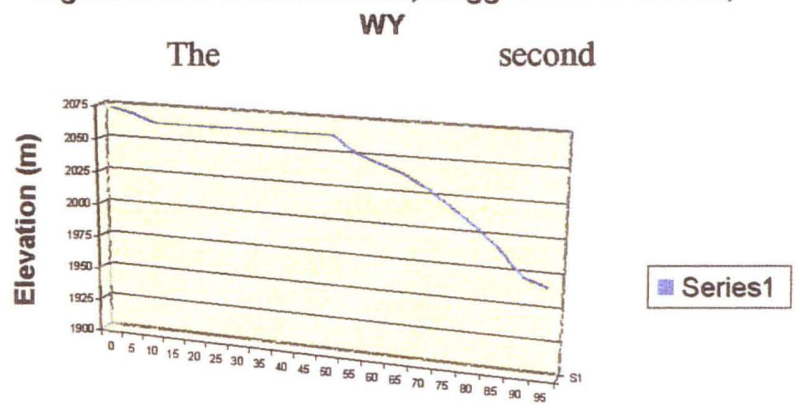

Distance from Flagg Ranch (km)

The second hydrologic parameter is average stream gradient. Figure 4 illustrates the stream gradient along the Snake River from Flagg Ranch to Moose. The overall gradient for this portion of the river is $0.64 \%$ with segments as high as $1.2 \%$ and as low as $0.24 \%$, not including the portions of the diagram that illustrate Jackson Lake. From Flagg Ranch to Jackson Lake the stream gradient averages $0.33 \%$, while from Jackson Lake Dam to Moose it averages more than $0.71 \%$, with a high of $1.2 \%$.

The analysis of the aerial photography produced 16 locations that displayed evidence of beaver activity. Unfortunately, not all of the locations were examined in the field because of time constraints. Eight of the locations, however, were field inspected and seven revealed old and abandoned occupations while one was an active lodge.

The six active dens (Map 1.) located along the Snake River did not have any consistency in environmental characteristics except that they were adjacent to the Snake River and had a food source nearby. The vegetation parameters do not display any particular pattern relative to the beaver den or the river channel except that percent crown cover decreases away from the river channel. Overall, the percent shrub cover did not exceed $70 \%$ with an average of $53 \%$ and the shrubs had an average height of $1.6 \mathrm{~m}$. The predominant tree species was Alder, followed by Cottonwood. Percent tree cover was substantially less than that of shrubs, with a mean of only $18 \%$ and only $40 \%$ of the trees having a dbh in the range $2.5-15 \mathrm{~cm}$.

Figure 4. Vegetation Characteristics adjacent to Beaver Bank Dens.

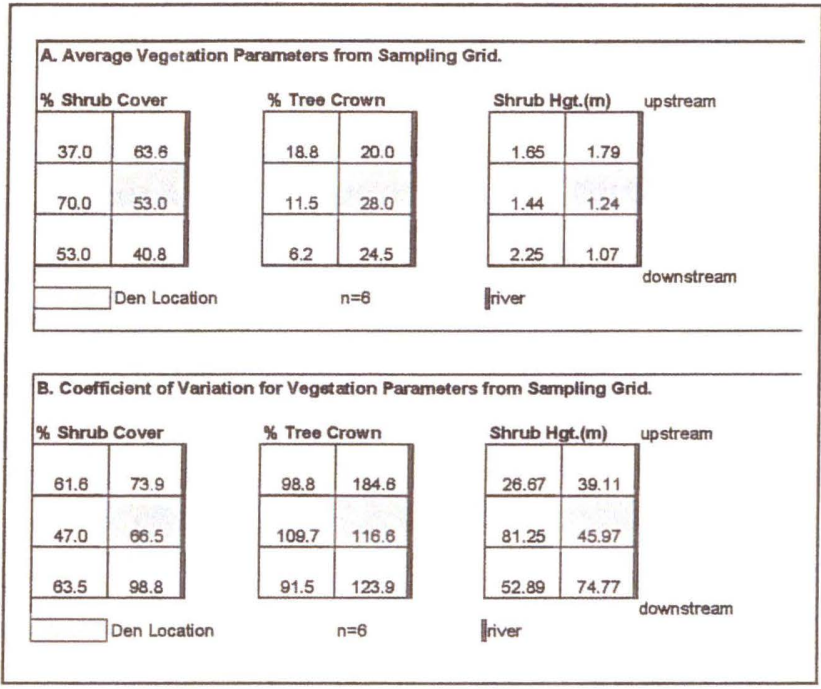

Map 1. Beaver Dens along Snake River, Grand Teton National Park, 2002.

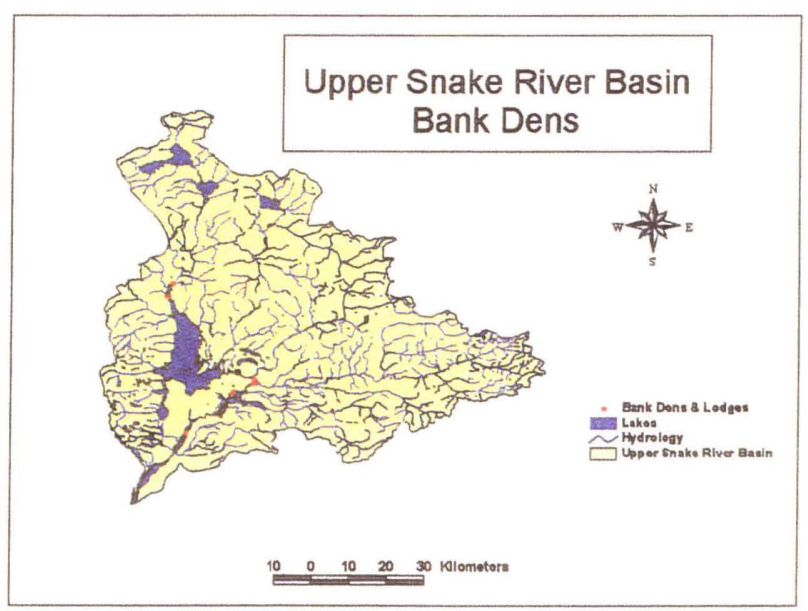

The six dens produce a density of only 0.125 colonies $/ \mathrm{km}$, whereas Collins in a shorter stretch of the river found 51 dens in $35.2 \mathrm{~km}$ for a density of 1.4 colonies $/ \mathrm{km}$, more than 10 times as many per $\mathrm{km}$. 
However, these numbers may be misleading because our study did not cover the tributaries and backchannels as did the Collins study (1976). Compared to the overall density of beavers found by ConsoloMurphy and Hansen (1993) in Yellowstone of $0.15 / \mathrm{km}$, they are almost the same. Though in Yellowstone, they found 71 dens over more than $450 \mathrm{~km}$ of river channel.

The distribution of beavers along the Snake River did not reveal any type of spatial pattern. A quadrat analysis of the beaver distribution confirmed this fact, the pattern is random, but somewhat toward clustered, VMR $=1.396 \quad\left(x^{2}=29.3, p=.001\right)$. The tendency toward clustered is only because of two dens within $2 \mathrm{~km}$ of each other.

Map 2. displays the distribution of dens relative to the land cover or vegetation types identified throughout the basin (WGISC, 2002). Upon closer inspection it can be observed that the two dens upstream from Jackson Lake are found in an area identified as shrub-dominated riparian, while the four dens downstream from Jackson Lake are found in the forest-dominated riparian. The difference between the two areas is a difference in the floodplain morphology. The upstream locations have a river that has a wider floodplain and unrestricted flow, while the downstream locations have a higher regulated flow and less movement in the floodplain.

Map 2. Land Cover in Upper Snake River Basin with Beaver Dens.

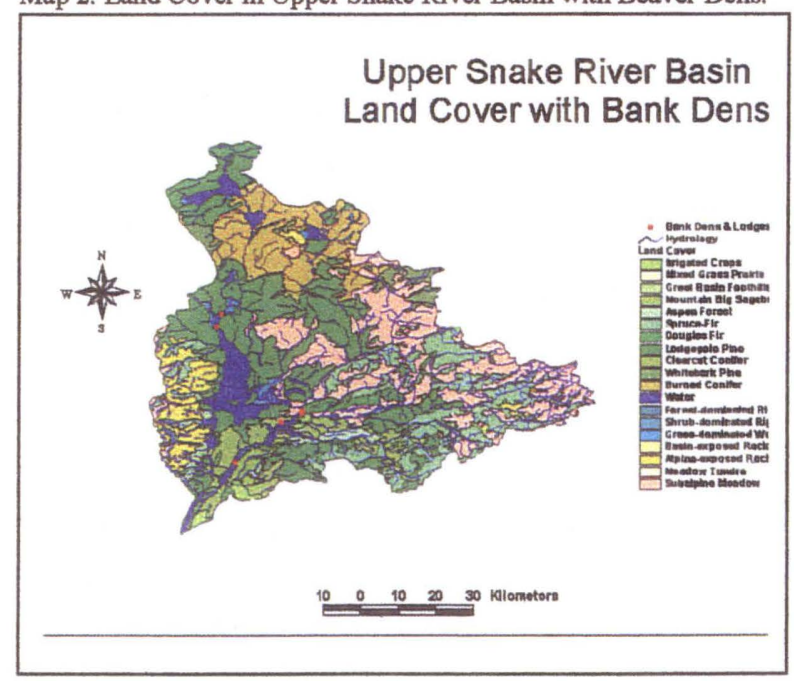

Because of the low number of den observations, it is not possible to statistically build the HSI model. As mentioned previously, the vegetation and hydrologic parameters were collected but no pattern or relationship could be determined. Thus, testing the model or adjusting the variables to the GNTP conditions was not possible.

\section{$\downarrow \quad$ SUMMARY AND RECOMMENDATIONS}

Beaver distributions along the Snake River from Flagg Ranch to Moose have not been completely identified. On the $48 \mathrm{~km}$ stretch of the main channel, only six bank dens were located. The back channels and main tributaries into the Snake River have not been investigated. At the dens that were found, the overall vegetation is shrub-dominated riparian upstream of Jackson Lake and forest-dominated riparian downstream of Jackson Lake. The average percent tree crown cover is only $18 \%$ and $53 \%$ for shrub cover. This portrays the fact that a majority of the bank dens may be in forest-dominated riparian areas, yet the trees are not dense and if there are shrubs (willows) they only constitute a little more than onehalf of the vegetation cover. The hydrologic characteristics at the den sites vary perceptively but there was not enough data to demonstrate a statistical variation. Again, the located population is not large enough to determine if there is any statistically significant difference between sites or uniformity to predict sites.

The significance of beavers to an ecosystem is well documented. In Grand Teton National Park it is essential to know their location, behavior, and habitat preference through long-term monitoring. This project was an initial attempt to gather information on location and habitat. Continuing beaver seasons will complete the inventory and provide an understanding of the factors that influence their location and their behavior.

\section{$\uparrow \quad$ LITERATURE CITED}

Allen, A.W. 1983. Habitat suitability index models: beavers. U.S. Fish and Wildlife Service, FWS/OBS-82/10.30 (revised), Ft. Collins, $\mathrm{CO}$.

Breck, S.W., K.R. Wilson, and D.C. Andersen. 2001. "The demographic response of bank-dwelling beavers to flow regulation: a comparison on the Green and Yampa rivers," Canadian Journal of Zoology, 79: 1957-1964. 
Collen, P. and R.J. Gibson. 2000. "the general ecology of beavers (Castor spp.), as related to their influence onstream ecosystems and riparian habitats," Reviews in Fish Biology and Fisheries, 10(4): 439-461.

Collins, T.C. 1976. Population Characteristics and habitat Relationships of Beavers, Caster canadensis, in northwest Wyoming. Unpublished Ph.D. thesis, University of Wyoming.

Consolo-Murphy, S. and D.D. Hanson. 1993. "Distribution of beaver in Yellowstone National Park, 1988-89," in Ecological Issues on Reintroducing Wolves into Yellowstone National Park, R.S. Cook, ed., USDI, NPS Scientific Monograph NRSM-93/22, pp. 38-48.

Consolo-Murphy, S. and R.B. Tatum. 1995. "Distribution of beaver in Yellowstone National Park, 1994," unpublished manuscript.

Gurnell, A.M. 1998. "The hydrogeomorphological effects of beaver dam-building activity," Progress in Physical Geography, 22(2): 167-189.

Hughes, J.W. and W.B. Cass. 1997. "Pattern and process of a floodplain forest, Vermont, USA: predicted responses of vegetation to perturbation," Journal of Applied Ecology, 34: 594-612.

Johnston, C.A. 1998. Geographic Information Systems in Ecology, London: Blackwell Sciences, pp. 124-127.

Johnston, C.A., J. Pastor and R.J. Naiman. 1993. "Effects of beaver and moose on boreal forest landscapes," in Landscape Ecology and GIS, R. Haines-Young, D.R. Green, and S.H. Cousins, ed., London: Taylor and Francis, pp. 237254.

Johnston, C.A. and R.J. Naiman. 1990. "The use of geographic information system to analyze long-term landscape alteration by beaver," Landscape Ecology, 4: 519.
Jonas, R.J. 1955. A Population and Ecological Study of the Beavers (Castor Canadensis) of Yellowstone National Park, Unpublished M.A. thesis, University of Idaho.

Kingsford, R.T. 2000. "Ecological impacts of dams, water diversions and river management on floodplain wetlands in Australia," Australian Ecology, 25: 109127.

Long, K. 2000. Beavers: A Wildlife Handbook, Boulder, CO: Johnson Books.

Lytle, D.A. 2002. "Flash floods and aquatic insect life-history evolution: evaluation of multiple models," Ecology, 83(2): 370-385.

Meentemeyer, R.K. and D.R. Butler. 1999. "Hydrogeomorphic effects of beaver dams in Glacier National Park, Montana," Physical Geography, 20(5): 436-446.

Nilsson, C. and M. Dynesius. 1994. "Ecological effects of river regulation on mammals and birds: a review. Regulated Rivers Research Management, 9: 45-53.

Nilsson,C., A. Ekbald, M. Gardfjell, and B. Carlberg. 1991. "Long term effects of river regulation on river margin vegetation," Journal of Applied Ecology, 28: 963-987.

Olson, R. and W.A. Hubert. 1994. Beaver: Water Resources and Riparian Habitat Manager, Laramie, WY: U.of Wyoming

Snodgrass, J.W. 1997. "Temporal and spatial dynamics of beaver-created patches as influenced by management practices in a south-eastern North American landscape," Journal of Applied Ecology, 34: 1043-1056,

Warren, E.R. 1926. A study of the beavers in the Yancey region of Yellowstone National Park. Roosevelt Wild Life Annals, 1: 1-191. 
Wheatley, M. 1994. Boreal Beavers (Castor Canadensis): Home Range, Territoriality, Food Habits and Genetics of a MidContinent Population. Unpublished Ph.D. thesis, Unversity of Manitoba, $350 \mathrm{pp}$. 